\title{
Kontribusi Informasi, Fasilitas, dan Loyalitas User dalam Menggunakan Aplikasi Fintech di Masa Pandemi Covid-19
}

\author{
Rendika Vhalery \\ Universitas Indraprasta PGRI
}

\begin{tabular}{l}
\hline ARTICLE INFO \\
\hline Article History: \\
Received May 09th, 2021 \\
Revised Jun $10^{\text {h }}, 2021$ \\
Accepted Aug $13^{\text {th }}, 2021$
\end{tabular}

\section{Keywords:}

Informasi;

Fasilitas;

Loyalitas;

Aplikasi;

Fintech.

\begin{abstract}
Covid-19 is still a hot issue in Indonesia that causes some changes such as in finance either buying or paying through fintech. In this study we aimed to find out the influence of information, facilities, and loyalty in using fintech applications in the covid-19 pandemic? . The research method used is quantitative with any type of associative research. The research population is a student of the economic education study program of Indraprasta University PGRI Jakarta. A study sample of 150 students. Data collection techniques use questionnaires in the form of google forms to make it easier to collect data due to the current lockdown situation. Data analysis techniques use multiple linear regressions. The results revealed that (1) there is an influence of information in using fintech applications during the covid-19 pandemic, (2) there is the influence of facilities in using fintech applications during the covid-19 pandemic, (3) there is a loyalty influence in using fintech applications during the covid-19 pandemic, and (4) there is the influence of information, facilities, and loyalty in using fintech applications during the covid-19 pandemic. The contribution of variable information, facilities, and user loyalty in using fintech applications during the covid-19 pandemic amounted to 0.471 or $47.1 \%$. Of the three variables that affect the use of fintechapplications, loyalty variables contribute the most.
\end{abstract}

Covid-19 masih menjadi isu hangat di Indonesia yang menyebabkan beberapa perubahan seperti di bidang keuangan baik pembelian atau pembayaran melalui fintech. Pada penelitian ini kami bertujuan untuk mengetahui pengaruh informasi, fasilitas, dan loyalitas dalam menggunakan aplikasi fintech di masa pandemi covid-19?. Metode penelitian yang digunakan yaitu kuantitatif dengan jenis penelitian asosiatif. Populasi penelitian adalah mahasiswa program studi pendidikan ekonomi Universitas Indraprasta PGRI Jakarta. Sampel penelitian sebanyak 150 mahasiswa. Teknik pengumpulan data menggunakan kuesioner berupa google form untuk mempermudah mengumpulkan data dikarenakan situasi lockdown saat ini. Teknik analisis data menggunakan regresi linear berganda. Hasil penelitian mengungkapkan bahwa (1) terdapat pengaruh informasi dalam menggunakan aplikasi fintech di masa pandemi covid-19, (2) terdapat pengaruh fasilitas dalam menggunakan aplikasi fintech di masa pandemi covid-19, (3) terdapat pengaruh loyalitas dalam menggunakan aplikasi fintech di masa pandemi covid-19, dan (4) terdapat pengaruh informasi, fasilitas, dan loyalitas dalam menggunakan aplikasi fintech di masa pandemi covid-19. Kontribusi variabel informasi, fasilitas, dan loyalitas user dalam menggunakan aplikasi fintech di masa pandemi covid-19 sebesar 0,471 atau sebesar $47,1 \%$. Dari ketiga variabel yang mempengaruhi penggunaan aplikasi fintech, variabel loyalitas memberikan kontribusi yang paling tinggi.

Corresponding Author:

Rendika Vhalery

Email: rendikavhalery31@gmail.com

How to Cite: Vhalery, R. (2021). Kontribusi Informasi, Fasilitas, dan Loyalitas User dalam Menggunakan Aplikasi Fintech di Masa Pandemi Covid-19. Sosio e-Kons, 13 (2), 99-108. http://dx.doi.org/10.30998/sosioekons.v13i2.9743 


\section{PENDAHULUAN}

Covid-19 masih menjadi isu hangat di Indonesia saat ini, pasien yang terkena kasus covid-19 terus meningkat setiap harinya. Berdasarkan data covid19 yang dikelola oleh pemerintah Indonesia, dilaporkan situasi penyebaran virus covid-19 pada tanggal 25 april 2021 di Indonesia yaitu sebanyak 1.641.194 orang berstatus positif, sebanyak 1.496 .126 orang dinyatakan sembuh, dan sebanyak 44.594 orang yang meninggal (www.covid19.go.id). Untuk menekan jumlah ini, pemerintah terus mengupayakan masyarakat untuk terus mengikuti protokol kesehatan yang berlaku.

Warga negara Indonesia dapat membantu meminimalisasi penyebaran covid-19 dengan cara mengikuti protokol kesehatan yaitu memakai masker, mencuci tangan dengan sabun, menjaga jarak, menjauhi kerumunan, serta membatasi mobilisasi dan interaksi (5M). Dikarenakan covid-19, ada beberapa perubahan yang akan terjadi pada kita. Pertama, kebiasaan hidup sehat. Kedua, kebiasaan menggunakan masker. Ketiga, kebiasaan mencuci tangan atau menggunakan handsanitizer. Keempat, perubahan offline ke online. Perubahan offline ke online yang sudah terasa di masyarakat yaitu sekolah (pembelajaran daring), kantor (work from home), perbankan (e-banking, sms-banking), transaksi online, atau keuangan (seperti financial technology).

Financial Technology atau yang biasa dikenal dengan fintech merupakan dua cabang ilmu yang dipadukan menjadi satu untuk mencapai sebuah tujuan. Dua cabang ilmu ini yaitu cabang ilmu keuangan dan cabang ilmu teknologi. Menurut Otoritas Jasa Keuangan (2016) fintech adalah sebuah inovasi pada industri jasa keuangan yang memanfaatkan penggunaan teknologi. Produk fintech biasanya berupa suatu sistem yang dibangun guna menjalankan mekanisme transaksi keuangan yang spesifik. Ada banyak penikmat produk ini, yang terdiri dari berbagai macam profesi, dari berbagai macam perusahaan, dari anak remaja hingga lansia.

Teknologi Keuangan (Fintech) adalah revolusi layanan keuangan online (Arner, Barberis, \& Buckley, 2015). Dalam arti yang lebih luas, fintech digambarkan sebagai pasar modern yang menggabungkan finansial dan teknologi untuk menyediakan jasa keuangan (Romanova \& Kudinska, 2017). Sedangkan menurut Yarli (2018) fintech merupakan segmen dinamis di persimpangan antara sektor jasa keuangan dengan teknologi dimana start up yang berfokus pada teknologi yang merupakan pendatang pasar baru berinovasi produk dan layanan yang saat ini disediakan oleh industri jasa keuangan tradisional. Berdasarkan beberapa pengertian dari pendapat tersebut, dapat disimpulkan bahwa fintech merupakan sebuah layanan keuangan yang terintegrasi dengan teknologi yang memudahkan perusahaan untuk memberikan jasa keuangan kepada konsumen secara cepat.

Menurut Nasution (2017) Ada beberapa macam jenis layanan fintech yang tersedia di Indonesia yaitu crowdfunding, aggregator, pinjaman, perencanaan keuangan, pembayaran, dan lainnya. OJK menambahkan beberapa jenis layanan fintech yang sedang berkembang dan memberikan solusi finansial bagi masyarakat Indonesia yaitu crowdfunding, microfinancing, P2P lending service, market comparison, dan digital payment system. OJK juga menjelaskan pengertian dari dari jenis layanan tersebut:

\section{Crowdfunding}

Crowdfunding atau penggalangan dana merupakan salah satu model fintech yang sedang populer di berbagai negara, termasuk Indonesia. Dengan adanya teknologi ini, masyarakat dapat menggalang dana atau berdonasi untuk suatu inisiatif atau program sosial yang mereka pedulikan. Contoh start-up fintech crowdfunding yang kini tengah populer di Indonesia adalah KitaBisa.com.

Belleflamme, Lambert, \& Schwienbacher (2010) mendefinikasikan crowdfunding sebagai konsep yang berakar dari crowdsourcing atau proses mendapatkan pendanaan yang memanfaatkan crowd (sekelompok orang) untuk mendapatkan ide, umpan balik dan solusi guna mengembangkan aktivitas perusahaan

2. Aggregator

Fintech aggregator adalah situs web atau aplikasi yang membantu masyarakat/konsumen (nasabah) untuk memperoleh informasi mengenai produk dan layanan jasa keuangan dengan 
menghimpun informasi, menyaring dan memperbandingkan produk dan layanan antar Lembaga Jasa Keuangan (LJK) secara digital.

3. P2P Lending Service (Pinjaman)

Fintech ini membantu masyarakat yang membutuhkan akses keuangan untuk memenuhi kebutuhan. Dengan fintech ini, konsumen dapat meminjam uang dengan lebih mudah untuk memenuhi berbagai kebutuhan hidup tanpa harus melalui proses berbelit-belit yang sering ditemui di bank konvensional. Salah satu contoh dari fintech yang bergerak dalam bidang peminjaman uang ini adalah AwanTunai, sebuah startup yang memberikan fasilitas cicilan digital dengan aman dan mudah.

4. Perencanaan Keuangan

Certified Financial Planner (CFP) - Financial Planning Standards Board (FPSB) Indonesia adalah suatu proses untuk mencapai tujuan hidup seseorang melalui pengelolaan keuangan secara terencana. Dalam menyusun perencanaan keuangan, seseorang akan dipengaruhi oleh kondisi (Live event) yang sedang dialaminya sehingga dengan demikian perencanaan keuangan akan bersifat spesifik. Perencanaan keuangan juga merupakan suatu proses yang berkesinambungan dan bersifat dinamis. Pada suatu saat, rencana tersebut dapat memerlukan penyesuaian. Manfaat dari perencanaan keuangan:

a) Adanya "arah dan arti" keputusan finansial seseorang

b) Seseorang bisa mengerti bagaimana setiap keputusan keuangan yang dibuat berdampak ke area lain dari keseluruhan situasi keuangan dirinya.

c) Dengan melihat setiap keputusan finansial sebagai bagian dari suatu keseluruhan, seseorang dapat mempertimbangkan efek jangka pendek dan jangka panjang atas tujuan-tujuan hidupnya.

d) Lebih mudah beradaptasi atas perubahan hidup dan merasa lebih aman karena tujuan-tujuannya berada di jalur yang tepat.

e) Perencanaan keuangan dapat dijadikan sebagai alat untuk bisa memenuhi kebutuhan-kebutuhan keuangan di masa kini dan masa depan.

\section{Microfinancing}

Microfinancing adalah salah satu layanan fintech yang menyediakan layanan keuangan bagi masyarakat kelas menengah ke bawah untuk membantu kehidupan dan keuangan mereka seharihari. Karena masyarakat dari golongan ekonomi ini kebanyakan tidak memiliki akses ke institusi perbankan, maka mereka pun mengalami kesulitan untuk memperoleh modal usaha guna mengembangkan usaha atau mata pencaharian mereka. Microfinancing berusaha menjembatani permasalahan tersebut dengan menyalurkan secara langsung modal usaha dari pemberi pinjaman kepada calon peminjam. Sistem bisnis dirancang agar return bernilai kompetitif bagi pemberi pinjaman, namun tetap attainable bagi peminjamnya. Salah satu startup yang bergerak dalam bidang microfinancing ini adalah Amartha yang menghubungkan pengusaha mikro di pedesaan dengan pemodal secara online.

6. Digital Payment System

Fintech ini bergerak di bidang penyediaan layanan berupa pembayaran semua tagihan seperti pulsa \& pascabayar, kartu kredit, atau token listrik PLN. Salah satu contoh fintech yang bergerak dalam digital payment system ini adalah Payfazz yang berbasis keagenan untuk membantu masyarakat Indonesia, terutama mereka yang tidak memiliki akses ke bank, untuk melakukan pembayaran berbagai macam tagihan setiap bulannya.

\section{Market Comparison}

Dengan fintech ini, user dapat membandingkan macam-macam produk keuangan dari berbagai penyedia jasa keuangan. Fintech juga dapat berfungsi sebagai perencana finansial. Dengan bantuan fintech, penggunanya dapat mendapatkan beberapa pilihan investasi untuk kebutuhan di masa depan. 
Indikator penggunaan fintech yang diungkapkan oleh Rahmatillah, Novirani, \& Fitri (2018) yaitu motivasi hedonis, pengaruh sosial, kebiasaan, dan niat perilaku. Namun, sedikit kami modifikasi menjadi motivasi keuangan, pengaruh sosial, kebiasaan, dan niat

Mahasiswa sebagai salah satu pengguna (user) produk fintech seharusnya mampu memanfaatkan produk sebaik mungkin. Namun, kenyataan di lapangan mengungkapkan sebaliknya. Rata-rata mahasiswa menggunakan fintech hanya pada saat terjadinya pandemi covid-19. Padahal, aplikasi fintech sudah dapat diakses sebelum pandemi covid-19 terjadi. Untuk memperkuat data penelitian dilakukan studi pendahuluan dengan cara melakukan wawancara dengan beberapa mahasiswa. Kami melakukan wawancara dengan lima orang mahasiswa. Hasil wawancara mengungkapkan bahwa mereka mengetahui apa itu fintech. Namun mereka tidak menggunakan fintech secara maksimal. Hal ini disimpulkan dari pendapat mereka yang mengatakan bahwa fintech digunakan apabila sedang dibutuhkan dan secara tidak sadar, mereka menggunakan fintech hanya keperluan yang tidak mendesak atau tidak begitu penting. Lebih lanjut, kami membagikan kuesioner kepada 30 mahasiswa untuk memperkuat data tersebut. Hasil kuesioner dari studi pendahuluan dapat dijabarkan pada tabel berikut ini:

Tabel 1.

Kategori Penggunaan Fintech

\begin{tabular}{clccc}
\hline Variabel & \multicolumn{1}{c}{ Indikator } & Rendah & $\begin{array}{c}\text { Kategori } \\
\text { Sedang }\end{array}$ & Tinggi \\
\hline Penggunaan Fintech & Motivasi keuangan & 16 & 9 & 5 \\
& & $(53,3 \%)$ & $(30 \%)$ & $(16,7 \%)$ \\
& Pengaruh sosial & 10 & 11 & 9 \\
& & $(33,3 \%)$ & $(36,7 \%)$ & $(30 \%)$ \\
& Kebiasaan & 20 & 7 & 3 \\
& \multirow{2}{*}{ Niat } & $(66,7 \%)$ & $(23,3 \%)$ & $(10 \%)$ \\
& & 15 & 10 & 5 \\
& & $(50 \%)$ & $(33,3 \%)$ & $(16,7 \%)$ \\
\hline
\end{tabular}

Berdasarkan tabel 1. dapat diketahui bahwa penggunaan fintech dapat dijelaskan sebagai berikut. Penggunaan fintech berdasarkan motivasi keuangan didominasi oleh mahasiswa yang memiliki motivasi keuangan yang rendah sebanyak 16 mahasiswa (53,3\%), mahasiswa yang memiliki motivasi keuangan sedang sebanyak 9 mahasiswa (30\%), dan mahasiswa yang memiliki motivasi keuangan tinggi hanya 5 mahasiswa (16,7\%). Artinya, motivasi keuangan yang dimiliki mahasiswa secara garis besar terkategori rendah. Penggunaan fintech berdasarkan pengaruh sosial menunjukkan mahasiswa yang dipengaruhi sosial rendah sebanyak 10 mahasiswa (33,3\%), mahasiswa yang dipengaruhi sosial sedang sebanyak 11 mahasiswa $(36,7 \%)$, dan mahasiswa yang dipengaruhi sosial tinggi sebanyak 9 mahasiswa $(30 \%)$. Artinya, pengaruh sosial yang ada pada mahasiswa secara garis besar terkategori sedang. Penggunaan fintech berdasarkan kebiasaan didominasi oleh mahasiswa yang memiliki kebiasaan yang rendah sebanyak 20 mahasiswa (66,7\%), mahasiswa yang memiliki kebiasaan sedang sebanyak 7 mahasiswa $(23,3 \%)$, dan mahasiswa yang memiliki kebiasaan tinggi hanya 3 mahasiswa $(10 \%)$. Artinya, kebiasaan yang dimiliki mahasiswa secara garis besar terkategori rendah. Penggunaan fintech berdasarkan niat didominasi oleh mahasiswa yang memiliki niat yang rendah sebanyak 15 mahasiswa $(50 \%)$, mahasiswa yang memiliki niat sedang sebanyak 10 mahasiswa $(33,3 \%)$, dan mahasiswa yang memiliki niat tinggi hanya 5 mahasiswa $(16,7 \%)$. Artinya, niat yang dimiliki mahasiswa secara garis besar terkategori rendah. Dapat di simpulkan bahwa penggunaan fintech oleh mahasiswa terkategori rendah. Hasil ini sejalan dengan hasil penelitian yang diungkapkan oleh Christanal (2019).

Rendahnya penggunaan fintech di kalangan mahasiswa dipengaruhi oleh berbagai macam faktor yang ada. Berbagai macam faktor yang mempengaruhi fintech terbentuk dari beberapa studi, penelitian, bahkan pengalaman yang didapat dari terjun ke lapangan. Faktor ini biasanya dipengaruhi oleh faktor yang berasal dari psikologis individu, faktor yang berasal dari internal individu, faktor yang berasal eksternal individu, bahkan faktor yang tidak terduga. Menurut Vhalery, Leksono, \& Anggresta (2020) dipengaruhi oleh beberapa faktor seperti informasi, fasilitas, dan loyalitas. 
Informasi pada masa sekarang bukan lagi menjadi suatu produk pelengkap melainkan sudah menjadi suatu kebutuhan utama (Muslih, \& Purnama, 2013). Informasi ini dibutuhkan oleh user untuk menjadi acuan untuk menggunakan fintech. Seseorang yang memiliki kemampuan mencari atau mempunyai informasi yang baik akan mudah pemproses bahkan mengelola fintech dengan efektif dan efisien. Seseorang yang kurang atau bahkan tidak memiliki informasi yang baik akan kesulitan untuk memakai atau bahkan mengelola fintech dengan sangat baik. Disisi lain, informasi juga dapat diproses oleh fintech untuk mengembangkan fintech itu sendiri. Oleh karena itu, informasi sangat dibutuhkan oleh user maupun fintech itu sendiri.

Informasi merupakan unsur pokok yang secara implisit melekat dalam konsep pembangunan yang terencana (Ahmad, 2012). Menurut Sutabri (2012) nilai dari suatu informasi didasarkan dari sepuluh sifatnya yaitu mudah diperoleh, luas dan lengkap, ketelitian, kecocokan, ketepatan waktu, kejelasan, keluwesan, dapat dibuktikan, tidak ada prasangka, serta dapat diukur. Sepuluh sifat ini membentuk dimensi informasi menjadi 3 dimensi yaitu akurat, tepat waktu, dan relevan. Utomo, Ardianto, \& Sisharini (2017) mengemukakan bahwa indikator untuk mengukur informasi yaitu relevan, akurat, penyajian informasi, kelengkapan, dan ketepatan waktu. Dapat disimpulkan indikator untuk mengukur informasi yaitu akurat, relevan, kegunaan, dan efektivitas

Fasilitas merupakan sarana dan prasarana yang disediakan untuk mempermudah melakukan sesuatu yang diinginkan. Fintech dapat berkembang apabila memberikan fasilitas yang mudah dijangkau atau mudah diakses oleh masyarakat (Baihaqi, 2018). Fasilitas juga dapat bersifat fisik (seperti sebuah ruangan, alat tulis, kantor, dll) dan nonfisik (seperti fitur, aplikasi, dII). Fasilitas dibutuhkan untuk terus mendukung pertumbuhan dan perkembangan fintech. User dapat memanfaatkan fasilitas yang disediakan fintech guna untuk mempermudah pekerjaan user itu sendiri.

Fasilitas merupakan segala sesuatu yang sengaja disediakan oleh penyedia jasa untuk dipakai serta dinikmati oleh konsumen yang bertujuan memberikan tingkat kepuasan yang maksimal (Mongkaren, 2013). Dimensi sebuah fasilitas terdiri dari fasilitas fisik dan fasilitas non-fisik (Zuardi, 2017)

Loyalitas adalah kesetiaan. Maksudnya, user yang memiliki loyalitas biasanya memanfaatkan fintech dengan senang hati dan mau menggunakannya setiap saat. Di lain pihak, perusahaan fintech membutuhkan loyalitas user guna untuk keberlangsungan hidup perusahaan. Hal ini dikarenakan loyalitas dapat menciptakan keuntungan bagi perusahaan (Rachmawati, 2014). Loyalitas sebagai kekuatan hubungan antara sikap individu terhadap suatu produk dan pemakaian berulang (Selang, 2013). Semakin tinggi loyalitas user terhadap platform fintech maka semakin besar keuntungan dan keberlangsungan hidup perusahaan itu. dan apabila semakin rendah loyalitas user terhadap platform fintech maka semakin kecil keuntungan dan keberlangsungan hidup perusahaan itu. maka, loyalitas juga merupakan bagian yang penting.

Loyalitas yaitu perilaku konsumen untuk melakukan pembelian kembali karena rasa puas yang didapakan atas pengalaman mencoba barang ataupun layanan, baik secara fisik ataupun melalui media online (Safarudin, Kusdibyo, \& Senalasari, 2020). Menurut Onsardi (2018), loyalitas adalah kesetiaan seorang atau sekelompok terhadap suatu produk dimana ia menggunakannya untuk kepentingan sehari-hari. Dan Aryani, \& Rosinta (2011) menambahkan bahwa loyalitas merupakan bagian terpenting pada penggulangan penggunaan. Loyalitas terbentuk dari lima tingkatan yaitu pembelian harga, Konsumen yang loyal dengan biaya peralihan, pembeli kebiasaan, pembeli apresiasi, dan konsumen yang setia (Wijayanto, 2015). Indikator loyalitas yaitu mengatakan hal yang positif, merekomendasikan ke teman, dan melakukan pembelian ulang (Ismail, 2014)

Penelitian tentang fintech pernah kami lakukan beberapa kali. Yang pertama, kami menganalisis faktor-faktor yang menghambat mahasiswa dalam menggunakan fintech. Hasil penelitian menunjukkan bahwa faktor-faktor penghambat penggunaan fintech di kalangan mahasiswa terdiri dari empat faktor, yaitu faktor dasar fintech, faktor individu, faktor manajemen sistem perusahaan dan faktor politik (Setyastanto, Leksono, \& Vhalery, 2019). Yang kedua, kami menganalisis faktor yang mempengaruhi penggunaan financial technology di perguruan tinggi. Hasil menunjukkan bahwa faktor yang 
mempengaruhi penggunaan financial technology yaitu faktor keamanan, produk yang ditawarkan, akses dan keuntungan, loyalitas, informasi, fasilitas, permintaan dan kualitas. Dalam penelitian ini, kami ingin melanjutkan penelitian sebelumnya dan menguji pengaruh variabel informasi, fasilitas, dan loyalitas user. Berdasarkan latar belakang tersebut, peneliti tertarik untuk melaksanakan penelitian dengan judul "Kontribusi Informasi, Fasilitas, dan Loyalitas User dalam Menggunakan Aplikasi Fintech di Masa Pandemi Covid-19".

Rumusan masalah pada penelitian ini ada empat yaitu apakah terdapat pengaruh informasi dalam menggunakan aplikasi fintech di masa pandemi covid-19?, apakah terdapat pengaruh fasilitas dalam menggunakan aplikasi fintech di masa pandemi covid-19?, apakah terdapat pengaruh loyalitas dalam menggunakan aplikasi fintech di masa pandemi covid-19?, dan apakah terdapat pengaruh informasi, fasilitas, dan loyalitas dalam menggunakan aplikasi fintech di masa pandemi covid-19?.

\section{METODE}

Metode penelitian yang digunakan yaitu kuantitatif dengan jenis penelitian asosiatif yang menguji untuk mengetahui pengaruh variabel independen terhadap variabel dependen. Populasi penelitian adalah mahasiswa program studi pendidikan ekonomi Universitas Indraprasta PGRI Jakarta. Sampel penelitian sebanyak 150 mahasiswa. Teknik pengumpulan data menggunakan kuesioner dengan kisikisi instrumen yang dapat dilihat pada tabel berikut ini:

Tabel 2.

Kisi-Kisi Instrumen

\begin{tabular}{ll}
\hline \multicolumn{1}{c}{ Variabel } & \multicolumn{1}{c}{ Indikator } \\
\hline Penggunaan Fintech & Motivasi keuangan \\
(Rahmatillah, Novirani, \& Fitri, 2018) & $\begin{array}{l}\text { Pengaruh sosial } \\
\text { Kebiasaan }\end{array}$ \\
& Niat \\
Informasi & Akurat \\
(Utomo, Ardianto, \& Sisharini, 2017) & Relevan \\
& Kegunaan \\
& Efektivitas \\
Fasilitas & Fisik \\
(Zuardi, 2017) & Non-Fisik \\
Loyalitas & Mengatakan hal yang positif \\
(Ismail, 2014) & Merekomendasikan Teman \\
& Melakukan Pembelian Ulang \\
\hline
\end{tabular}

Teknik pengumpulan data menggunakan bantuan website google form untuk mempermudah mengumpulkan data dikarenakan situasi lockdown saat ini. Teknik analisis data menggunakan regresi linear berganda untuk menguji keempat hipotesis yang ada, yaitu ada pengaruh informasi dalam menggunakan aplikasi fintech di masa pandemi covid-19, ada pengaruh fasilitas dalam menggunakan aplikasi fintech di masa pandemi covid-19, ada pengaruh loyalitas user dalam menggunakan aplikasi fintech di masa pandemi covid-19, dan ada pengaruh informasi, fasilitas, dan loyalitas user dalam menggunakan aplikasi fintech di masa pandemi covid-19. Semua perhitungan data penelitian menggunakan bantuan software SPSS versi 24.0.

\section{HASIL DAN PEMBAHASAN}

Berdasarkan perhitungan statistik menggunakan rumus regresi linear berganda dapat dilihat hasil penelitian sebagai berikut: 
Tabel 3.

Hasil Regresi Linear Berganda

\begin{tabular}{ccc|c|c|c|c}
\hline \multicolumn{2}{l}{ Model } & \multicolumn{2}{c}{ Unstandardized Coefficients } & Standardized Coefficients & t & Sig. \\
& B & Std. Error & Beta & & 5,999 &, 000 \\
\hline 1 & 21,289 & 3,549 & & $-2,012$ &, 046 \\
\hline & (Constant) &,- 120 &, 060 &, 265 & 2,493 &, 014 \\
\hline Informasi &, 249 &, 100 &, 476 & 4,592 &, 000 \\
\hline
\end{tabular}

Sumber: SPSS yang diolah oleh Peneliti (2021)

Berdasarkan hasil output SPSS pada tabel 3 diketahui nilai $Y=21,289-0,120 X_{1}+0,249 X_{2}+$ $0,443 X_{3}$. Nilai t tabel pada penelitian ini adalah 1,976 yang di dapat dari nilai derajat kebebasan $n-2=$ $150-2=148$ dengan nilai taraf kesalahan sebesar $5 \%$ atau 0,05. Lalu, nilai $t$ tabel ini akan dibandingkan dengan nilai $t$ hitung. Nilai $t$ hitung dapat dilihat pada tabel 3 dan hipotesis dapat di simpulkan sebagai berikut:

\section{Pengaruh informasi dalam menggunakan aplikasi fintech di masa pandemi covid-19}

Berdasarkan hasil perhitungan statistik pada tabel 3 diketahui bahwa nilai thitung untuk variabel informasi sebesar $-2,012$ dengan nilai signifikansi $0,046<$ dari nilai tabel sebesar $-1,976$ dengan nilai signifikansi 0,050 . Dapat simpulan bahwa $\mathrm{HO}$ ditolak dan Ha diterima yang berarti terdapat pengaruh informasi dalam menggunakan aplikasi fintech di masa pandemi covid-19 secara signifikan. Hasil penelitian ini sejalan dengan hasil penelitian yang dikemukakan oleh Silalahi dan Pramedia (2018) yang mengungkapkan bahwa informasi berpengaruh terhadap pengguna fintech.

Informasi berupa oral atau data dapat membantu user dalam menambah wawasan dalam penggunaan sesuatu. Informasi pada penggunaan aplikasi fintech dimasa pandemi covid-19 dapat membawa sesuatu yang positif, dimana user dapat memanfaatkan informasi ini untuk kepentingan pribadi atau keluarga bahkan masyarakat/kelompok. Sedangkan dari sisi fintech, informasi fintech itu sendiri menyediakan berbagai macam informasi untuk kepentingan user dalam mengoperasikan fintech itu sendiri. Menurut Silalahi \& Pramedia (2018) informasi yang tersebar dari beberapa indikator juga dapat menjadi penunjang penggunaan aplikasi fintech sehingga pengguna percaya dan nyaman dalam menggunakan aplikasi fintech dan terus menggunakan aplikasi fintech dimasa mendatang.

2. Pengaruh fasilitas dalam menggunakan aplikasi fintech di masa pandemi covid-19

Berdasarkan hasil perhitungan statistik pada tabel 3 diketahui bahwa nilai thitung untuk variabel fasilitas sebesar 2,493 dengan nilai signifikansi 0,014 > dari nilai tabel sebesar 1,976 dengan nilai signifikansi 0,050 . Dapat simpulan bahwa $\mathrm{HO}$ ditolak dan Ha diterima yang berarti terdapat pengaruh faslitas dalam menggunakan aplikasi fintech di masa pandemi covid-19 secara signifikan. Fasilitas yang disediakan oleh fintech bermanfaat untuk mempermudah user dalam mengelola aplikasi fintech menjadi lebih simpel dan gampang digunakan, sehingga membuat aktivitas user menjadi lebih sederhana (Faizah, Subhan, \& Fielnanda 2020). Fasilitas juga dapat dikatakan sebagai investasi jangka panjang (Prastika, 2019), dan fasilitas yang disediakan aplikasi fintech digunakan sebagai motivasi untuk menarik minat user dalam menggunakan aplikasi fintech. Fasilitas ini dapat berupa sebuah layanan. Fasilitas pada aplikasi fintech juga merupakan sebuah inovasi yang disediakan oleh pihak fintech berdasarkan keinginan user.

3. Pengaruh loyalitas user dalam menggunakan aplikasi fintech di masa pandemi covid-19

Berdasarkan hasil perhitungan statistik pada tabel 3 diketahui bahwa nilai thitung untuk variabel loyalitas user sebesar 4,592 dengan nilai signifikansi $0,000>$ dari nilai tabel sebesar 1,976 
dengan nilai signifikansi 0,050 . Dapat simpulan bahwa $\mathrm{HO}$ ditolak dan Ha diterima yang berarti terdapat pengaruh loyalitas user dalam menggunakan aplikasi fintech di masa pandemi covid-19 secara signifikan. hasil penelitian ini sejalan dengan hasil penelitian yang dikemukakan oleh Muhammad (2020) bahwa loyalitas berpengaruh terhadap keputusan penggunaan fintech. Loyalitas user dalam menggunakan aplikasi fintech menunjukkan sebuah kesetiaan user pada penggunaan aplikasi tersebut. Adanya pengaruh loyalitas pada penggunaan aplikasi fintech dikarenakan loyalitas membangun kepercayaan user pada platform fintech dan platform fintech menyediakan semua kebutuhan yang diinginkan user. Hal ini menunjukkan bahwa loyalitas dan fintech saling menguntungkan satu sama lainnya dan dapat berjalan bersama ketika tujuan mereka sama.

Adapun hipotesis berikutnya yang dapat diketahui dari perhitungan uji F. Hasil uji $F$ dapat dilihat pada tabel berikut:

Tabel 4.

Hasil F hitung

\begin{tabular}{llc|c|c|c|c}
\hline Model & & Sum of Squares & Df & Mean Square & F & Sig. \\
\hline \multirow{2}{*}{1} & 3704,427 & 3 & 1234,809 & 43,314 &, 000 \\
\cline { 2 - 7 } & Regression & 4162,246 & 146 & 28,509 & & \\
\cline { 2 - 7 } & Residual & 7866,673 & 149 & & & \\
\cline { 2 - 6 } & \multicolumn{2}{l}{ Total } & \multicolumn{3}{l}{}
\end{tabular}

4. Pengaruh informasi, fasilitas, dan loyalitas user dalam menggunakan aplikasi fintech di masa pandemi covid-19

Berdasarkan hasil perhitungan statistik pada tabel 4 diketahui bahwa nilai $F_{\text {hitung }}$ untuk variabel informasi, fasilitas, dan loyalitas user sebesar 43,314 dengan nilai signifikansi $0,000>$ dari nilai $F_{\text {tabel }}$ sebesar 2,432 dengan nilai signifikansi 0,050. Dapat simpulan bahwa H0 ditolak dan Ha diterima yang berarti terdapat pengaruh informasi, fasilitas, dan loyalitas user dalam menggunakan aplikasi fintech di masa pandemi covid-19 secara signifikan.

Untuk mengetahui kontribusi variabel informasi, fasilitas, dan loyalitas user dalam menggunakan aplikasi fintech di masa pandemi covid-19 dapat dilihat pada tabel berikut ini:

Tabel 5.

Kontribusi Penelitian

\begin{tabular}{lr|r|r|r}
\hline Model & $\mathbf{R}$ & R Square & Adjusted R Square & Std. Error of the Estimate \\
\hline 1 &, $686^{\mathrm{a}}$ &, 471 &, 460 & 5,339 \\
\hline Sumber: SPSS yang diolah oleh Peneliti (2021) & &
\end{tabular}

Dari tabel 5 diketahui bahwa variabel kontribusi informasi, fasilitas, dan loyalitas user dalam menggunakan aplikasi fintech di masa pandemi covid-19 sebesar 0,471 atau sebesar 47,1\% sedangkan $52,9 \%$ berasal dari luar variabel yang diteliti.

\section{SIMPULAN DAN SARAN}

Hasil penelitian menunjukkan bahwa terdapat pengaruh informasi dalam menggunakan aplikasi fintech di masa pandemi covid-19, terdapat pengaruh fasilitas dalam menggunakan aplikasi fintech di masa pandemi covid-19, terdapat pengaruh loyalitas dalam menggunakan aplikasi fintech di masa pandemi covid-19, dan terdapat pengaruh informasi, fasilitas, dan loyalitas dalam menggunakan aplikasi fintech di masa pandemi covid-19. Adanya pengaruh dari semua variabel dikarenakan setiap variabel mempunyai peranan penting. Setiap variabel mempunyai fungsi dan kinerja masing-masing yang saling berhubungan dan dapat meningkatkan operasional penggunaan aplikasi fintech itu sendiri. Kontribusi variabel informasi, fasilitas, dan loyalitas user dalam menggunakan aplikasi fintech di masa 
pandemi covid-19 sebesar 0,471 atau sebesar 47,1\%. Dari ketiga variabel yang mempengaruhi penggunaan aplikasi fintech, variabel loyalitas memberikan kontribusi yang paling tinggi.

Ada beberapa saran yang dapat diberikan. Pertama, penggunaan aplikasi fintech masih banyak didominasi atau dipengaruhi oleh variabel lain selain yang dikaji dalam penelitian ini. Oleh karena itu ada baiknya penelitian berikutnya menguji variabel tersebut. Kedua, keterbatasan teori dan pola pikir yang berbeda dapat menciptakan persepsi yang berbeda pula. Oleh karena itu ada baiknya penyesuaian atau penyelarasan teori bahkan konseptual untuk mendapatkan pengetahuan yang layak. Ketiga, penelitian ini hanya berfokus pada dasar penggunaan aplikasi fintechnya saja, ada baiknya dikemudian hari ada tindak lanjut untuk mengetahui manfaat, risiko, atau dampak sejenisnya dari penggunaan apikasi fintech atau platform fintech secara umum.

\section{REFERENCES/DAFTAR PUSTAKA}

Ahmad, A. (2012). Perkembangan Teknologi Komunikasi Dan Informasi: Akar Revolusi Dan Berbagai Standarnya. Jurnal Dakwah Tabligh, 13(1), 137-149.

Arner, D., Barberis, J., \& Buckley, R. (2015). The Evolution of FinTech: A New Post-Crisis Paradigm?, $0-45$.

Aryani, D., \& Rosinta, F. (2011). Pengaruh kualitas layanan terhadap kepuasan pelanggan dalam membentuk loyalitas pelanggan. BISNIS \& BIROKRASI: Jurnal IImu Administrasi dan Organisasi, 17(2).

Baihaqi, J. (2018). Financial Technology Peer-To-Peer Lending Berbasis Syariah di Indonesia. TAWAZUN: Journal of Sharia Economic Law, 1(2), 116-132.

Belleflamme, P., Lambert, T., \& Schwienbacher, A. (2010). Crowdfunding: An industrial organization perspective. In Prepared for the workshop Digital Business Models: Understanding Strategies', held in Paris on June (pp. 25-26).

Christanal, K. (2019). Analisis literasi keuangan, penggunaan produk Fintech, dan inklusi keuangan pada mahasiswa Universitas Katolik Parahyangan.

Nurul Faizah, E., Subhan, S., \& Fielnanda, R. (2020). Pengaruh Persepsi Kemudahan Penggunaan, Pengetahuan Konsumen, Dan Efektivitas Terhadap Minat Bertransaksi Menggunakan Financial Technology (Studi Pada Mahasiswa Fakultas Ekonomi Dan Bisnis Islam UIN STS Jambi).

Satuan Tugas Penanganan COVID-19. (2021) .Data Sebaran virus COVID-19 di Indonesia. Url: https://www.covid19.go.id diakses pada hari senin, tanggal 26 April 2021.

Ismail, R. (2014). Pengaruh Kualitas Layanan, Kualitas Produk dan Kepuasan Nasabah Sebagai Prediktor dalam Meningkatkan Loyalitas Nasabah. Jurnal Organisasi dan Manajemen, 10(2), 179-196.

Korkiakoski, E. (2017). Fintech-Yritysten Tarjoamien Vertaislainapalveluiden Käyttö Rahoituksessa Ja Sijoittamisessa.

Mongkaren, S. (2013). Fasilitas dan Kualitas Pelayanan Pengaruhnya Terhadap Kepuasan Penguna Jasa Rumah Sakit Advent Manado. Jurnal EMBA: Jurnal Riset Ekonomi, Manajemen, Bisnis dan Akuntansi, 1(4).

Muhammad, F. (2020). Pengaruh keamanan, promosi dan loyalitas pelanggan terhadap keputusan penggunaan gopay pada karyawan pt. Bakrie pangripta loka cakung jakarta timur. S1 Manajemen, 1-22.

Muslih, M. T., \& Purnama, B. E. (2013). Pengembangan Aplikasi Sms Gateway Untuk Informasi Pendaftaran Peserta Didik Baru Di SMAN 1 Jepara. IJNS-Indonesian Journal on Networking and Security, 2(1).

Nasution, D. S. (2017). Urgensi Fintech Dalam Kurikulum Pendidikan Tinggi. IqtlshaduNa - Jurnal Ekonomi Syariah, 8(2), 116-129. 
OJK. "Gunakan Fintech Aggregator Dan Tentukan Produk/Layanan Jasa Keuangan Impianmu". Url: https://sikapiuangmu.ojk.go.id/FrontEnd/CMS/Article/30679. Diakses pada hari rabu, tanggal 28 April 2021.

Yuk mengenal fintech! Keuangan digital yang tengah naik daun. Url: https://sikapiuangmu.ojk.go.id/FrontEnd/CMS/Article/10468. Diakses pada hari rabu, tanggal 28 April 2021.

Apa Itu Rencana Keuangan?. Url: https://sikapiuangmu.ojk.go.id/FrontEnd/CMS/Category/130. Diakses pada hari rabu, tanggal 28 April 2021.

Otoritas Jasa Keuangan. Url: https://www.ojk.go.id. Diakses pada hari senin, tanggal 26 April 2021.

Onsardi, O. (2018). Loyalitas Karyawan pada Universitas Swasta di Kota Bengkulu. COSTING: Journal of Economic, Business and Accounting, 2(1), 1-13.

Prastika, Y. (2019). Pengaruh Financial Technology (FINTECH) Terhadap Profitabilitas Perbankan Syariah (Studi Komparasi Bank Syariah Mandiri, BNI Syariah, dan Bank Mega Syariah Periode 2016-2018).

Rachmawati, R. (2014). Pengaruh Kepuasan Terhadap Loyalitas Pelanggan. TEKNOBUGA: Jurnal Teknologi Busana dan Boga, 1(1).

Rahmatillah, I., Novirani, D., \& Fitri, R. N. (2018). Analisis Pengaruh Perilaku Penggunaan Teknologi Fintech Pada Generasi Millennial Di Kota Bandung.

Romanova, I., \& Kudinska, M. (2017). Banking and fintech: a challenge or opportunity? Contemporary Studies in Economic and Financial Analysis, 98, 21-35. https://doi.org/10.1108/S1569375920160000098002.

Safarudin, A., Kusdibyo, L., \& Senalasari, W. (2020, September). Faktor-Faktor Pembentuk Loyalitas Generasi Z dalam Menggunakan Financial Technology E-wallet. In Prosiding Industrial Research Workshop and National Seminar (Vol. 11, No. 1, pp. 1073-1078).

Selang, C. A. (2013). Bauran pemasaran (marketing mix) pengaruhnya terhadap loyalitas konsumen pada fresh mart Bahu Mall Manado. Jurnal EMBA: Jurnal Riset Ekonomi, Manajemen, Bisnis dan Akuntansi, 1(3).

Setyastanto, A. M., Leksono, A. W., \& Vhalery, R. (2019). Analysis Of The Factors Which Hinder Undergraduate Students In Using Fintech. Jurnal Inovasi Pendidikan Ekonomi (JIPE), 9(2), 99106.

Silalahi, R., \& Pramedia, D. P. (2018). Analisis Faktor Keberhasilan Fintech Payment Dengan Menggunakan Model DeLone Dan McLean.

Sutabri, T. (2012). Konsep sistem informasi. Yogyakarta: Andi.

Utomo, L. T., Ardianto, Y. T., \& Sisharini, N. (2017). Pengaruh kualitas sistem, kualitas informasi, kualitas layanan, terhadap kepuasan pengguna sistem informasi akademik universitas merdeka malang. Jurnal Teknologi dan Manajemen Informatika.

Vhalery, R., Leksono, A. W., \& Anggresta, V. (2020). The Analysis of Factors Influencing Financial Technology Usage in Higher Education. Dinamika Pendidikan, 15(1), 40-52.

Wijayanto, K. (2015). Pengaruh kualitas pelayanan terhadap kepuasan dan loyalitas nasabah bank. Jurnal Manajemen Dayasaing, 17(1), 38-45.

Yarli, D. (2018). Analisis Akad Tijarah pada Transaksi Fintech Syariah dengan Pendekatan Maqhasid. YUDISIA: Jurnal Pemikiran Hukum Dan Hukum Islam, 9(2).

Zuardi, M. (2017). Pengaruh Fasilitas Fisik dan Fasilitas Non Fisik terhadap Kepuasan Pelanggan di Pasar JBBC Medan Johor. Jurnal Riset Akuntansi dan Bisnis, 16(2). 